\title{
Transfiguratus est ante eos. Desarrollo teológico de la Transfiguración del Señor en un sermón inédito del siglo xvIII"
}

\author{
Darwin Eduardo Flórez Angarita*
}

Recepción: 28 de mayo de 2020 • Aprobación: 14 de junio de 2020

\section{Resumen}

En el Archivo Histórico de la Provincia de San Luis Bertrán-Colombia (AHPSBC), se encuentran diversos sermones predicados por los frailes dominicos de la Nueva Granada durante el siglo xvirI. Tomando como base los métodos histórico-crítico y teológico, se hace aquí un análisis teológico del sermón de Transfiguración: Transfiguratus est ante eos (Mat 17, 2), predicado el 06 de agosto de 1786; mediante la identificación de categorías teológicas basadas tanto en fuentes bíblicas y patrísticas como de los demás escritores eclesiásticos propuestos por el autor. Debido a que estos textos gozan de un lenguaje icónico y apologético, se brindan los aportes a la historia de la teología a través del análisis paleográfico, archivístico, diplomático y codicológico del documento.

Palabras clave: homilética, Transfiguración, icono, belleza, fe, esperanza.

Artículo de investigación producto del semillero de investigación Fuentes para la Historia de la Iglesia y de la Teología de la Facultad de Teología de la Universidad Santo Tomás. Citar como: Flórez Angarita, D. E. (2020). Transfiguratus est ante eos. Desarrollo teológico de la Transfiguración del Señor en un sermón inédito del siglo xviII. Albertus Magnus, XI(2), 105-137. https://doi.org/10.153322/5005413.6402

* Universidad Santo Tomás, Bogotá, Colombia. orcid: https://orcid.org/0000-0001-7683291X. Correo electrónico: darwin.eduar24@gmail.com 


\title{
Transfiguratus est ante eos. Theological development of the Transfiguration of the Lord in an unpublished sermon of the 18 th century
}

\begin{abstract}
In the Historical Archive of the Province of San Luis Bertrán-Colombia (AHPSBC, for its initials in Spanish), there are several sermons preached by the Dominican friars of New Granada during the 18th century. Based on the historical-critical and theological methods, a theological analysis is made of the Transfiguration sermon: Transfiguratus est ante eos (Matthew 17:2), preached on August 6, 1786; through the identification of theological categories based on biblical and patristic sources, as well as the other ecclesiastical writers proposed by the author. Since these texts have an iconic and apologetic language, contributions to the history of theology are provided through the paleographic, archival, diplomatic and codicological analysis of the document.
\end{abstract}

Keywords: homiletics, Transfiguration, icon, beauty, faith, hope.

\section{Transfiguratus est ante eos. Desenvolvimento teológico da Transfiguração do Senhor em um sermão inédito do século XVIII}

\section{Resumo}

No Arquivo Histórico da Província de San Luis Bertrán-Colômbia (AHPSBC), encontram-se diversos sermões pregados pelos frades dominicanos da Nova Granada durante o século xviII. Tomando por base os métodos histórico-crítico e teológico, faz-se uma análise teológica do sermão da Transfiguração: Transfiguratus est ante eos (Mt 17,2), pregado em 6 de agosto de 1786; a partir da identificação de categorias teológicas baseadas tanto nas fontes bíblicas e patrísticas quanto nos demais escritores eclesiásticos propostos pelo autor. Por serem textos com uma linguagem icônica e apologética, as contribuições para a História da Teologia são fornecidas por meio da análise paleográfica, arquivística, diplomática e codicológica do documento.

Palavras-chave: homilética, Transfiguração, ícone, beleza, fé, esperança. 


\section{Introducción}

El semillero de investigación Fuentes para la Historia de la Iglesia y de la Teología, de la Facultad de Teología de la Universidad Santo Tomás de Bogotá, ha llevado a cabo el primer contacto, inventario, catalogación e interpretación del Fondo Sermones, perteneciente al Archivo Histórico de la Provincia de San Luis Bertrán de Colombia, que contiene el ejercicio homilético de los frailes mendicantes en la Nueva Granada durante los siglos xviII y xIx. Para usufructuar de la mejor manera la producción teológica de este patrimonio documental y su proyección al quehacer académico de nuestro tiempo, se han aplicado los principios del método teológico y del histórico-crítico documental. Es decir, se ha efectuado el análisis contextual, paleográfico, codicológico y diplomático de cada unidad archivística. Asimismo, la exégesis bíblica y patrística y el desarrollo interpretativo de varios sermones inéditos del siglo xvin desde algunas escuelas teológicas contemporáneas.

Con el presente trabajo de investigación se quiere ofrecer una lectura integral, en la perspectiva de tres categorías descubiertas en la hermenéutica interna del sermón Transfiguratus est ante eos (Mt 17, 2), predicado en Santafé el 6 de agosto de 1786, a saber: la Transfiguración como una acción al alcance de toda la humanidad, la teología catafática de los iconos y la Revelación en Jesucristo. Este artículo se propone responder a preguntas como: ¿qué análisis cristológico y antropológico podemos llevar adelante, desde las categorías teológicas de un fraile predicador del siglo Xvin? ¿Qué aportes al quehacer teológico actual ofrece un texto homilético en el contexto de la Ilustración neogranadina? Se trata, también, de conducir la actividad intelectual del aula a los ambientes sociales a través de un discernimiento crítico del esquema: Kerygma-Didaskalia-Homilía, propio de la evangelización, y emparentar interdisciplinariamente: teología, historia de la Iglesia y literatura.

\section{La Transfiguración: una acción al alcance de toda la humanidad}

Para el desarrollo teológico de la Transfiguración, en la primera parte del artículo, se aborda la etimología griega y latina del término para comprender hermenéuticamente la intención propia del Evangelio. Posteriormente, se sustentará la aplicación antropológica de la Transfiguración, en el sermón Transfiguratus est ante eos (Mt. 17, 2) (Anónimo, 1786, 1 r). 
El término Transfiguración se abordará a partir de tres dimensiones específicas: la Transfiguración en la persona de Jesús, la desarrollada en el cristiano y la configurada en la Iglesia como cuerpo místico. La primera dimensión hace referencia al evento teofánico acaecido en la persona de Jesús, narrado en los Evangelios sinópticos (Mt 17, 1-8; Mc 9, 2-8; Lc 9, 28-36).

La segunda comprensión se vincula a la posibilidad que tiene la humanidad de ser transfigurada. El sermón hace una exégesis, comparando tipológicamente la Transfiguración de Jesús con la de Daniel o Quileab, el segundo hijo de David que fue engendrado con Abigail. Daniel era declarado por los áulicos como bastardo e hijo del anterior matrimonio de su madre con Nabal; es decir, se ponía en duda la paternidad de David sobre Daniel, de allí que el monarca rogara a Dios para lograr una mayor semejanza con su hijo ${ }^{1}$. Esta tipología es presentada por nuestro predicador de 1786 como una Transfiguración acaecida en un hombre, no en Dios. Por último, el concepto debe ser comprendido en su relación con la Iglesia como cuerpo místico de Cristo. Se tiene una intención escatológica, visualizando en Jesús transfigurado la glorificación que le espera a la Iglesia.

\subsection{Abordaje etimológico}

\subsubsection{Etimología griega}

El término utilizado por Mateo 17, 2 al hablar de Transfiguración es $\mu \varepsilon \tau \alpha \mu$ o@фó $\omega$, que significa "transformar, cambiar de apariencia". El prefijo $\mu \varepsilon \tau \alpha$-significa "en-

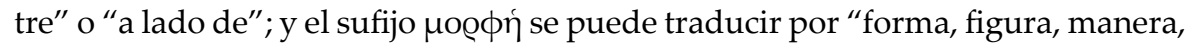
manifestación visible". Se evidencia que el término hace referencia a un valor netamente físico y perceptible por los sentidos. Su opuesto es el término $\mu \varepsilon \tau \alpha v o t \alpha$, que hace referencia a un cambio, pero en otra perspectiva. El sufijo voú s significa "intelecto, facultad de pensar, alma, mente, corazón", es decir, hace referencia a una transformación en sentido espiritual e interno, a diferencia de la anterior que tiene una intención netamente física (Vásquez Alarcón y Vergara Abril, 2019, pp. 273, 274, 283, 293, 294).

En el Nuevo Testamento, $\mu \varepsilon \tau \alpha \mu$ o@фó $\omega$ aparece también en 2 Corintios 3, 18 y se relaciona directamente con el sermón.

1 Esta ampliación del texto es inspirada en el argumento hecho por el Rabino Rashi al comentar el segundo libro de Samuel, debido a que la Sagrada Escritura no profundiza en información sobre el segundo hijo de David. 


\section{Co 3, 18}

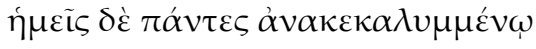

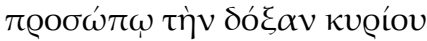

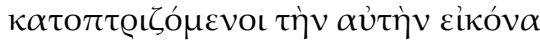

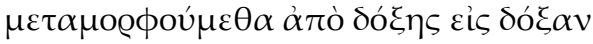

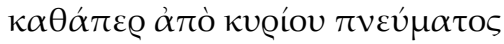
(Nestle - Aland, 1991, pág. 477).
Más todos nosotros, que con el rostro descubierto reflejamos como en un espejo la gloria del Señor, nos vamos transformando en esa misma imagen cada vez más gloriosos: así es como actúa el Señor, que es Espíritu.

El término $\mu \varepsilon \tau \alpha \mu о \varrho \phi o u ́ \mu \varepsilon \theta \alpha$ se asocia a una transformación física de la persona. Con ello se confirma la intención de Mateo: Jesús realiza una manifestación de su perfección, cambiando físicamente su apariencia y mostrando la glorificación de su persona, delante de Pedro, Santiago y Juan. Así, el término griego hace referencia a una transformación física, no interior de Jesús. Según el sermón, usando tipológicamente $\mu \varepsilon \tau \alpha \mu$ oффoú $\mu \varepsilon \theta \alpha$, Quileab es prototipo de dicha transformación física: la raíz hebrea de este nombre significa semejante a su padre, de manera que el hijo desemejante a David ahora toma su aspecto físico.

\subsubsection{Etimología latina}

Valiéndose de la Vulgata ${ }^{2}$, el autor del sermón usa el término: transfiguratus, participio perfecto pasivo masculino del verbo transfiguro: "transfigurar, metamorforsear, transformar, mudar de forma" como nos dice el Diccionario ilustrado latino-español VOX de Larousse (2011). Compuesto de trans: "del otro lado" (De Miguel, 1889) y figuro: "figurar, dar forma, disponer" (De Miguel, 1889, p. 377): cambiar la forma o la figura de una cosa. Dicha palabra es utilizada cinco veces en el Nuevo Testamento y una en el Antiguo Testamento (Peultier, Etienne y Gantois, 1939, p. 1140), entre ellas:

\section{Sab 16, 25}

Propter hoc et tunc in omnia transfigu- Por eso, también entonces, adaprata, omnium nutrici gratiae tuae deserviebat, ad voluntatem eorum qui a te desiderabant (De San Miguel, 1846) tando todas las formas, servía a tu generosidad que a todos sustenta, conforme al deseo de los necesitados.

2 Durante este período los mendicantes de la Nueva Granada se valieron de le Vulgata de Jerónimo, como después fue publicada en Migne y es la utilizada en los escritos de su colección. Aquí se utiliza la versión de Don Felipe De San Miguel (1846). 
La perícopa refiere la finalidad de la creación, que "adopta diferentes formas". Así, las creaturas se transfiguran para servir a Dios.

\section{Co 4,6}

Haec autem, fratres, transfiguravi in En esto, hermanos, me he puesto como me et Apollo, propter vos: ut in nobis ejemplo a mí y a Apolo, en orden a vodiscatis, ne supra quam scriptum est, sotros; para que aprendáis de nosotros unus adversus alterum infletur pro aquello de "No propasarse de lo que alio (De San Miguel, 1846, p. 1110). está escrito" y para que nadie se engría en favor de uno contra otro.

El texto indica el servicio que Pablo presta en la comunidad, de manera que las acciones apostólicas son una forma de Transfiguración, término entendido como ejemplo de: Pablo es modelo, que permite percibir a Cristo mediante sus actos.

\section{Co 11, 13-15}

${ }^{13} \mathrm{Nam}$ ejusmodi pseudoapostoli sunt operarii subdoli, transfigurantes se in apostolos Christi. ${ }^{14}$ Et non mirum: ipse enim Satanas transfigurat se in angelum lucis. ${ }^{15}$ Non est ergo magnum, si ministri ejus transfigurentur velut ministri justitiae: quorum finis erit secundum opera ipsorum (De San Miguel, 1846, p. 1126).
${ }^{13}$ Porque esos tales son unos falsos apóstoles, unos trabajadores engañosos, que se disfrazan de apóstoles de Cristo. ${ }^{14} \mathrm{Y}$ nada tiene de extraño: que el mismo Satanás se disfraza de ángel de luz. ${ }^{15}$ Por tanto, no es mucho que sus ministros se disfracen también de ministros de justicia. Pero su fin será conforme a sus obras.

Aquí se entiende transfiguro como disfraz; es decir, una acción externa ocurrida en los ministros que no poseen las condiciones propias para la misión apostólica, enseñando al margen de los elementos kerigmáticos y aprovechándose de la evangelización para lucrarse. Por tanto, la Transfiguración es algo externo, pero en sentido metafórico: las acciones evidencian que los ministros no contienen en sí a Cristo y su misión evangelizadora: Transfiguración negativa.

El abordaje bíblico permite apreciar la Transfiguración como un hecho físico y perceptible a los sentidos, idea clara en el autor del sermón al proponer la transformación corporal del hijo de David, que es externa y comprendida no solo en la apariencia corporal del cristiano, sino en las actitudes que él mismo posee, 
siendo las acciones en su vida una manera coherente de comprender su creencia y práctica de la fe: Transfiguración positiva.

\subsection{Transfiguración moral del cristiano}

\subsubsection{Sentido eclesial de la Transfiguración desde la patrística}

Los Padres no dudan de la historicidad de la Transfiguración, a diferencia de algunos teólogos del siglo XIx ${ }^{3}$. Según Ambrosio, la Iglesia, como cuerpo místico de Jesús, es invitada a transfigurarse, a adquirir la "gloria corporal". Identifica a los apóstoles con todo el género humano y con el número de los días previos a la resurrección, entendiéndose como una invitación a la salvación de toda la humanidad, pero reservada para aquellos que creen en la Trinidad (Ambrosio, 1845, p. 1702). Por ello, es comprendida en sentido escatológico y no en el presente del hombre.

Es significativa la interpretación de los Padres sobre la perícopa de Mateo: "sus vestidos se volvieron blancos como la luz" (Mt 17, 2). Cirilo de Jerusalén relaciona la vestidura con el bautismo: "Y los que estáis cubiertos por el pernicioso vestido del vicio [...] despojaos del hombre viejo que se corrompe en los deseos del vicio [...] y vestíos del hombre nuevo que es renovado según el conocimiento de Aquel que le creó" (Cirilo de Jerusalén, 1945, p. 30). De manera que las vestiduras son la evidencia del cambio en el hombre. Agustín comprende alegóricamente la vestidura con la Iglesia: "sus vestidos son su Iglesia. En efecto, los vestidos, si no los sostiene el que los viste, caen al suelo" (Agustín, 1845, p. 490). Con ello, exhorta a los creyentes a la unión íntima con Cristo, concedida plenamente en la salvación eterna.

Además de esta dimensión escatológica y metafísica, desarrollada por Cirilo, Ambrosio y Agustín, el sermón ofrece una visión de la Transfiguración en lo referente a su aplicabilidad antropológica de manera física y perceptible, al ser humano creyente, comprendiendo las vestiduras como algo físico: tienen la blancura de la nieve celeste y dejan traspasar la gloria que procede de Cristo, es decir, irradian la luz que está detrás de ellas (Anónimo, 1786, 1 v).

3 Los teólogos que apoyan el argumento de la Transfiguración como una visión imaginaria pospascual son Joachim Gnilka en su texto Una "creación de la comunidad" primitiva, Hernan Paul Müller en Die Verklärung Jesu y Blizler y Taylor en sus Obras completas. Véase (Marfiori y Cuello, 2010, p. 81). 


\subsubsection{Acciones que transfiguran}

La idea de una Transfiguración del hombre ha sido desarrollada por algunos teólogos contemporáneos: "la Transfiguración de Cristo no afecta a su cuerpo solo en la otra vida, sino también en esta vida" (Cantalemessa, 2003, p. 15), interpretando a Pablo afirman que el hombre es capaz de reflejar a Cristo $(2$ Co 3,18$)$, el cual se transforma en su camino a la gloria. Con esto, la Transfiguración no queda encerrada en una relevancia futura, sino que se desarrolla en la vida terrenal como una coherencia del cristiano entre lo que se cree y se vive.

De lo anterior, se comprende una relación estrecha entre la promesa escatológica (comprensión de la patrística) y la coherencia de vida, como una de las condiciones que se necesitan para alcanzar la salvación: "Las faltas y los errores no son las transgresiones de una ley abstracta, sino que el apartarse de Cristo, de la figura que quiso configurarse en nosotros y guiarnos a nuestra propia forma, debe ser lo que debemos reconocer como nuestra culpa" (Bonhoeffer, 2000, p. 107).

Por este motivo, cada falta o error puede llevarnos a la pérdida de la figura que tenemos de Cristo. La configuración con Él permite al creyente manifestarlo de forma externa, practicando en la cotidianidad la fe en Jesús. Martínez Lozano al hablar del "talante lúcido" (2013, p. 73) del cristiano, utiliza el término "actitudes constructivas" (2013, p. 73), evidenciando una manera pragmática de la fe. Toma como ejemplos el servicio y la solución de problemas. A partir de esto, la vida del hombre se comprende como una manifestación de la persona de Jesús, por medio de sus acciones.

\section{Teología catafática del icono: una descripción metafísica}

La teología catafática históricamente es vinculada con la teología de Occidente, pero este segmento desarrolla la tesis del icono como una manifestación catafática en Oriente. Para ello se aborda primero la distinción terminológica entre substancia y accidente, aplicada a Dios dentro del arte cristiano y la teología del icono. En un segundo momento se desarrolla la teología del icono desde algunos autores de la patrística. Por último, se estudia la visión de icono como una defensa de la Encarnación: lo pintores clásicos, no conocieron a Cristo, por tanto, no pueden plasmar a Dios. 
Desde la segunda mitad del siglo iv hasta la primera del siglo vin evolucionaron diversas controversias acerca de la legitimidad del culto a las imágenes. En Occidente el icono tenía una función pedagógica y catequética, en Oriente era una manifestación teológica de Dios, que hacía presente al prototipo ${ }^{4}$.

El sermón De Transfiguración se apoya en la perspectiva occidental al afirmar que "ninguno de los célebres pintores que aplaudió la antigüedad, ni Apeles, ni Protógenes, ni Zeuxis, supieron disponer de tal suerte los colores que representase la imagen, la substancia de su original" (Anónimo, 1786, 1 r). La evidencia es explicita: la pintura no es Dios substancialmente, pero no niega su representación.

\subsection{Substancia y accidente del Verbo encarnado}

Las categorías metafísicas hacen parte fundamental del ejercicio teológico cristiano, como lo atestigua el depositum fidei. En esta coordenada el sermón indica que ninguno de los pintores anteriormente nombrados plasmó la substancia de Dios, solo los accidentes (Anónimo, 1786, 1r). En la época de esta predicación, los postulados del pensamiento neogranadino estaban influenciados por la llamada "segunda escolástica española", en la que predominó el pensamiento de Francisco Suárez, autor de las Disputationes Metaphisicae. En ellas se independizaba la metafísica de la teología, dando autonomía a su estudio (Zabalza Iriarte, 2004, p. 113). A esto se suman los cursos catedráticos, conservándose nueve de ellos llamados In Metaphysicam, Disputationes metaphysicae, De causis, de los siglos

4 Se tiene evidencia del arte desarrollado en los baptisterios y las catacumbas de los primeros siglos, previos al Giro Teodosiano, donde se representaban escenas de la vida de Jesús. Esta práctica es heredada de los judíos que plasmaban las historias del Antiguo Testamento en las sinagogas, después de la liberación de los persas. Durante los primeros siglos, las pinturas evocaban un lenguaje simbólico centralizado en Jesús: el pez y el pastor. En el s. Iv "la iglesia deja de ser $[\ldots]$ un sencillo y acogedor espacio de la familia cristiana para convertirse en templo y palacio del Emperador Celeste", de allí que inicie con más fuerza la implementación del arte dentro de los lugares de culto. En este siglo tomó fuerza la figura alegórica del Cordero, resaltando la vestidura blanca de lana y los textos de la candida grex para el bautismo. En Roma (siglo Iv) las catacumbas eran ornamentadas con referencia a la vida del apóstol Pedro, quien tenía la potestad de conceder el perdón de los pecados. Desde estos puntos, se empieza a evidenciar una influencia en la comprensión del sacramento de la Penitencia, ligado a la comunión particular con el Obispo de Roma: reflejo claro de la función catequética del arte en Occidente. En Oriente, se generará una intención distinta, posterior a las controversias cristológicas: la iconografía era más solemne e impresionante, con el fin de orientar la contemplación hacia el misterio de la persona divina de Cristo; intención explícitamente teológica (Plazaola, 1996, pp. 26-75). Acerca de la crisis iconoclasta, véanse las siguientes fuentes: Álvarez Gómez (1998, pp. 91-150) y Vilanova (1987, pp. 309-360). 
XVI-XVII (Zabalza Iriarte, 2004, pp. 125-127). La metafísica no era ajena al desarrollo intelectual de las escuelas y universidades de Santafé durante el siglo xvir.

El sermón emplea los términos de la Metafísica: substancia y accidente, afirmando que "los pintores que aplaudió la antigüedad, ni Apeles, ni Protógenes, ni Zeuxis supieron disponer de tal suerte los colores que representase la imagen, la substancia de su original: ellos figuraron los accidentes, pintaron las cualidades, delinearon la figura y los externos lineamientos del cuerpo; pero jamás pudieron descifrar la substancia del original" (Anónimo, 1786, 1 r). La substancia es el elemento más importante de cada cosa, distinguiéndose por medio de dos aspectos: primero, el sujeto en que se asientan los accidentes, de allí que se derive del latín sub-stat, lo que está debajo; segundo, una característica de subsistencia, es decir, que no es otra cosa, sino que es en sí misma (Alvira, Chavell y Melendo, 1989, p. 54). Los accidentes son variables sujetas a la substancia y dependientes de ella (Alvira, Chavel, y Melendo, 1989, p. 56). Sucede, pues, como con el agua: su temperatura permite que varíe de estado (líquido, sólido o gaseoso), sin perder su composición molecular $\left(\mathrm{H}_{2} \mathrm{O}\right)$ (Alvira, Chavell y Melendo, 1989, p. 53). Su substancia no cambia a pesar de los accidentes.

Los pintores plasman en sus obras los accidentes o cualidades de Cristo encarnado, pero no su substancia. El Segundo Concilio de Nicea afirma "sobre la imagen de Cristo, [...] que esta es semejante a Cristo según el hombre, no según la substancia” (Franquesa, 2002, p. 43), a pesar de esto, “el que adora una imagen, adora a la persona en ella representada" (Dezinger y Hünermann, 1999, p. 282). De manera que no es una simple representación, sino una presencia del prototipo que representa, plasmando los accidentes del Dios que se encarna.

Cristo no es una pintura o retrato de Dios, es imagen de Dios, "única y perfecta en quien somos imagen de Dios, fuimos creados y en quien somos recreados. Por la participación en la Pascua del Verbo encarnado estamos llamados a reflejar la imagen de Cristo glorioso" (Lorda y Álvarez, 2016, pág. 32). Cristo es Sacramento del Padre.

\section{2. "Dios pudo pintar en Jesucristo la figura de su misma substancia"}

\subsubsection{En contra}

En contra de la teología del icono encontramos a Clemente, Orígenes y Eusebio de Cesarea, los tres de la escuela de Alejandría. Eusebio escribe una carta a 
Constanza, hermana del emperador Constantino, debido a su petición de realizar una imagen de Cristo. El obispo de Cesarea expresa que es imposible realizar una imagen:

Me escribiste también sobre alguna supuesta imagen de Cristo que querías que te enviara. Pero, ¿qué clase de cosa es lo que tú llamas imagen de Cristo? No sé lo que te indujo a solicitar que se pintara una imagen de Nuestro Salvador. ¿Qué clase de imagen de Cristo buscas? ¿La verdadera e inalterable que tiene sus características esenciales, o la que adoptó para nuestra salvación cuando asumió la forma de un siervo? (Eusebio de Cesarea, 1999, p. 60)

Eusebio apela al pasaje de Éxodo $20,4^{5}$ :

Pero si lo que quieres pedirme es la imagen, no de su forma transformada en la de Dios, sino la de la carne mortal antes de su transformación, es que has olvidado ese pasaje en el que Dios establece la ley de que ningún retrato se puede hacer de lo que está en el cielo o en la tierra (Eusebio de Cesarea, 1999, p. 60).

Su postura es radical: no es posible debido a que solo plasma el carácter terrenal del Hijo de Dios, además está prohibido por la Sagrada Escritura. Cabe recordar que Eusebio fue partidario en un primer momento de la doctrina arriana, después aceptó Nicea I, pero condujo su pensamiento a un desarrollo mo-

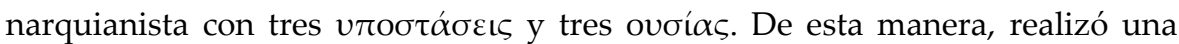
propuesta doctrinal entre los arrianos y los nicenos (Drobner, 1999, pp. 246-247). El origen del argumento de Eusebio parte de que se puede plasmar solo la naturaleza humana del Hijo, la celestial solo puede ser contemplada en la visión beatífica. El problema es discutido y solucionado por la Iglesia por medio del término comunicatio idiomatum ${ }^{6}$.

Orígenes, en su escrito Contra Celso, manifiesta su rechazo a la promoción de las imágenes. Afirma sobre los sabios del Imperio: “Y es de ver cómo los que alardean de su propia sabiduría y de la ciencia de Dios se postran ante la semejanza

5 No te harás escultura ni imagen alguna ni de lo que hay arriba en los cielos, ni de lo que hay abajo en la tierra, ni de lo que hay en las aguas debajo de la tierra.

6 El término communicatio idiomatum se refiere a que "el mismo y único Verbo, Hijo de Dios es el hombre Jesús; por eso de Dios en cuanto encarnado se pueden predicar atributos humanos, y del hombre, en cuanto unido personalmente al Verbo, se pueden predicar atributos divinos" (González de Cardedal, 2001, p. 224). 
de una imagen de hombre mortal, para honor, dicen, de Dios mismo" (Orígenes, 1967, p. 391). A esto se le suma la lucha contra las imágenes de Ártemis, sus devotos "dejaron desvanecerse en sus razonamientos, y su corazón insensato se revolcó entre tinieblas e ignorancia acerca del culto de Dios" (Orígenes, 1967, p. 395). Es evidente que Orígenes genera un discurso apologético contra la religión clásica, rechazando el culto a las imágenes como un fenómeno cultural propio de los paganos, siendo el cristianismo la manera inteligible de madurar la fe.

Orígenes invita a Celso a volver a sus leyes clásicas que estaban en contra de la fabricación de imágenes y proponían una orientación a lo supremo: "solo se tenía por Dios al Dios supremo, y ningún fabricante de imágenes tenía derecho de ciudadanía" (Orígenes, 1967, p. 267). Orígenes menciona a dos pintores que aparecen en el sermón: Zeuxis y Apeles, concluyendo que la imagen por excelencia es Cristo, quien está por encima de cualquier talla realizada por escultores o pintores.

Clemente de Alejandría ataca las costumbres paganas con el deseo de atraer sus adeptos al mensaje cristiano. En contra de la idolatría, manifiesta que "la estatua de Dios -realmente el único Dios- es espiritual y no perceptible por los sentidos" (Clemente de Alejandría, 2008, p. 183). Dios no es percibido por medio de lo tangible, sino que sus fuentes ahondan en las prácticas dogmáticas y doctrinales del cristianismo.

En lo referente al arte y la pintura, afirma: "parecida es la pintura; el arte sea alabado, pero que no engañe al hombre como si fuera una verdad" (Clemente de Alejandría, 2008, p. 195). Esta enunciación es similar a una hecha por el sermón: "ninguno de los célebres pintores [...] supieron disponer de tal suerte los colores que representase la imagen, la substancia de su original" (Anónimo, 1786, 1 r), de manera que la influencia desarrollada por algunos de los Padres es explicita en la concepción teológica que tiene el sermón sobre el icono.

\subsubsection{A favor}

Basilio de Cesarea, explicando la relación intratrinitaria del Padre, el Hijo y el Espíritu Santo, afirma: “como en el Hijo se ve al Padre, así en el Espíritu Santo se ve al Hijo [...] imposible, en efecto, ver la imagen de Dios invisible, si no es en la iluminación del Espíritu" (2012, p. 217). Se hace evidente la necesidad del Espíritu Santo dentro de la manifestación del Hijo, justificando la utilización de iconos, gracias a que "en la imagen verás la inefable belleza del Modelo" (Basilio de Cesarea, 2012, p. 143), es decir, quien ve al Hijo, ve la majestuosidad de la Trinidad. 
Otros aportes son dados por Asterio de Amasea: “Contemplando aquello [el martirio de Santa Eufemia] me deshago en lágrimas, y la emoción me impide hablar. El pincel había pintado con tanto realismo las gotas de sangre como si manaran de los labios, y tuvieras que retirarte llorando" (1996, p. 80). Por su parte, Teodoro Estudita sostiene: “No es la susbtancia la que se adora a la imagen, sino la figura del prototipo que en ella está impresa, quedando sin adoración la substancia de la imagen" (1996, p. 198).

Otros Padres defienden el uso de imágenes gracias a su función pedagógica. Gregorio Magno, asegura: "lo que un libro proporciona al que lo lee, eso es lo que una pintura ofrece a los analfabetos que la contemplan, en ella leen los que no tienen letras"' (1996, p. 176). Así, las pinturas se convierten en elementos catequéticos en ayuda de la formación doctrinal. Lactancio sostiene una postura específica: evocar la memoria de quien se representa. Él manifiesta que las imágenes se inventaron para "retener el recuerdo de aquellos que nos han sido arrebatados por la muerte o separados por la ausencia" (Lactancio, 1996, p. 20) con esto, la imagen de Cristo evoca directamente al recuerdo de lo que él fue.

Toda la problemática anteriormente desarrollada, fue definida primero por el Concilio de Hieria (año 754) el cual, auspiciado por el emperador Constantino $\mathrm{V}$, condenó la iconodulía. Su implementación fue compleja, debido a que no tenía el apoyo de gran parte del clero y de los monjes, provocando un rechazo popular. Esto hizo que se convocara un nuevo Concilio en Nicea debido a los disturbios acaecidos en Constantinopla sobre los partidarios del iconoclasmo, con el fin de que se refutaran las posturas tomadas por los obispos en Hieria.

La teología del Concilio de Nicea II confirmó la imagen como semejante al prototipo, signo y realidad: "tanto más se mueven los que éstas miran al recuerdo y deseo de los originales y a tributarles el saludo y adoración de honor" (Dezinger y Hünermann, 1999, p. 282). El modelo trasciende al afirmar que se rinde culto a quien representa.

Nicea parte de los fundamentos de Juan Damasceno, quien basándose en los postulados de la unión hipostática, manifiesta que "el cuerpo de Dios también es Dios" (2004, p. 94), donde a través del icono "no venero la materia sino que venero al creador de la materia que se ha vuelto materia a causa mía y en la materia ha aceptado habitar y a través de la materia ha realizado mi salvación" (Juan Damasceno, 2004, p. 94).

En relación con lo anterior, el sermón sostiene que "Dios con el pincel del entendimiento fecundo" (Anónimo, 1786, 1r) fue quien "pudo pintar en Jesucristo la figura de su misma substancia" (Anónimo, 1786, 1r). Confirmando que Cristo no es un simple prototipo del Padre, sino que es su imagen plena: verdadero Dios 
humanizado. Substancialmente los pintores no pueden plasmar la esencia, que solo es conferida del Padre al Hijo, pero pueden generar artísticamente prototipos del Verbo Encarnado.

La expresión del predicador es teológicamente arriesgada, pero debe ser comprendida en el contexto que se realiza: un sermón. Desde esta perspectiva, la intención del autor no es generar nuevos conceptos teológicos, sino manifestar, de manera retórica, dentro del contexto del icono, la procesión del Hijo, aunque genere ambigüedades. Al utilizar la expresión "pincel del entendimiento fecundo" podría caer en la interpretación de comprender al Hijo como una creatura del Padre, situación que es solucionada posteriormente al afirmar que son de la misma substancia, manifestando la manera en que substancialmente procede el Hijo del Padre. Sin embargo, ¿qué comprende el predicador al hablar de "figura de su misma substancia"? Es inviable afirmar que el Padre pintó en Jesús algo parecido a él, de allí que "figura" deba comprenderse como una distinción existente entre las personas de la Trinidad: el Padre es diferente al Hijo desde el concepto "persona".

\subsection{La encarnación frente a los pintores clásicos}

El sermón menciona los nombres de tres artistas clásicos: Apeles, Protógenes y Zeuxis. Algunos Padres, entre ellos Orígenes, mencionan a varios de estos pintores para atacar algunas acciones propias del paganismo.

Apeles fue el pintor de Alejandro Magno. Tuvo tal impacto que diferentes artistas del Renacimiento plasmaron escenas de su vida, especialmente Boticelli. Sus representaciones se enfocaban en los dioses "humanos", a diferencia de los dioses clásicos abstractos. De Alejandro representó un retrato que se conserva en Éfeso y se destaca por su colorido (Lozano, 2014, p. 202), y la batalla en Issos, que fue llevada luego al mosaico (Lozano, 2014, p. 205).

Protógenes, contemporáneo y rival de Apeles. Vivió en la isla de Rodas y es conocido por pintar a Jalisos, héroe de la misma ciudad, Sátiro descansando, el Páralo y el Ammoniades, Alejandro Magno, la Madre de Aristóteles y otras obras (1920, p. 1180).

Zeuxis se ubica en la segunda mitad del siglo v a. C., pintando junto con Parrahasios y Apollodoros (Blanco Freijeiro, 2011, p. 323), quien fue su maestro. Se afirma que dicha escuela da apertura a la pintura del arte moderno (Blanco Freijeiro, 2011, p. 323). Era llamado por Plinio el "legislador de la pintura" (De La Maza, 2013, p. 30). No se conserva ninguna obra suya, solo menciones hechas 
en escritos antiguos, de allí que se sepa de la existencia de pinturas como Zeus, Eros, Maryas atado, Penélope, Herakles niño estrangulando a las serpientes, y la familia de centauros (Blanco Freijeiro, 2011, p. 324).

El sermón está datado en 1786, veintitrés siglos después de estos autores. La tradición cristiana ya había generado una teología propia en torno a las imágenes, pronunciándose de manera dogmática sobre el tema. ¿Por qué el deseo de citar pintores clásicos y no cristianos? ¿Por qué no mencionar a Miguel Ángel, Rafael, Durero o cualquiera otro representativo del cristianismo? La idea se concentra específicamente en el concepto “Encarnación” mesiánica.

Cristo es "Imagen de Dios invisible, Primogénito de toda la creación"7, es decir, es Dios humanizado, por ello, solo los artistas posteriores a la Revelación del Hijo pueden plasmar artísticamente su figura. Los pintores clásicos no poseen la capacidad explicita de refigurarlo, porque no conocen su imagen. Germán de Constantinopla al hacer referencia a la religión clásica, asegura:

El representar en los iconos del Señor la imagen de su fisionomía según la carne viene a ser una refutación de los herejes que neciamente afirman que él no se hizo hombre de verdad, sino solamente en apariencia, y es también una guía y ayuda para aquellos que no son del todo capaces de remontarse a las alturas de la contemplación espiritual, sino que tienen necesidad de alguna representación material para recuerdo de lo que han escuchado, y esta se les hará más útil y provechosa cuanto más la busquen y deseen. (Germán de Constantinopla, 2001, pp. 186-187)

Con esto, se puede afirmar la posibilidad de plasmar artísticamente a Cristo en la Encarnación del Verbo, no a Dios mismo. Los pintores clásicos, al no conocer al Hijo, no pueden representar artísticamente la imagen de Dios.

\subsection{Teología catafática del icono}

Las representaciones en imágenes teológicamente se comprenden de manera diferente en Oriente y Occidente. Los occidentales no utilizan la palabra icono, debido a las distinciones que tienen con los orientales: el icono en Oriente tiene una intención más teológica que artística, por ello sus imágenes tienen algunas desproporciones corporales que no se asemejen directamente con la realidad.

7 Colosenses 1, 15. 
Para Occidente, "es un puro recuerdo, una evolución artística de un hecho o de una persona sagrada, expresada con cierto realismo" (Codina, 1997, p. 121). Oriente lo comprende desde una teología de la belleza, como "uno de los sacramentales, más en concreto el de la presencia personal" (Evdokimov, 1991, p. 181), es decir, para Occidente posee una función catequética y de rememorización, para Oriente es toda una teología.

La teología apofática parte de que conocemos de Dios lo que no es, de allí que se "prefieran los epítetos negativos para expresar los [...] dogmáticos, las "definiciones" en sentido estricto" (Felmy, 2002, p. 57). Ejemplo de ello son los conceptos doctrinales emitidos en Calcedonia: "que se ha de reconocer a un solo y mismo Cristo Señor, Hijo unigénito en dos naturalezas, sin confusión, sin cambio, sin división, sin separación" (Dezinger y Hünermann, 1999, p. 163).

Felmy, sobre el icono de la Transfiguración del Monasterio de Santa Catalina del Monte Sinaí, expresa: "lo curioso es que la mandorla ${ }^{8}$ en la que se halla Cristo se va haciendo cada vez más oscura hacia el interior, en círculos concéntricos, y en cambio hacia el exterior se va haciendo cada vez más luminosa" (2002, p. 57), concluyendo que "hace referencia a la absoluta imposibilidad de conocer a Dios" (2002, p. 57). La postura de Felmy comprende algunas partes del icono como manifestaciones de la teología apofática, en comparación con el arte occidental que demuestra gran cantidad de luminosidad en pinturas sobre la Transfiguración o la Resurrección.

Ahora bien, Codina tiene una posición sutilmente diferente a la de Felmy frente al tema del icono, afirmando que en ellos no cabría una teología apofática, debido a que manifiestan realidades teológicas de lo que es Dios dentro de todo su ahondado misterio. Por ello, el icono es una expresión tácita de teología catafática en Oriente:

La teología apofática [...] reconoce que este Dios se ha manifestado en Cristo, posee sus imágenes y símbolos, sus sacramentos. Junto a la vía apofática del silencio existe una vía catafática o simbólica de acceso a Dios. Cristo es el icono del Padre, y la Iglesia icono del Reino. (Codina, 1997, p. 122)

Con esto se pueden apreciar dos tesis que confluyen en la comprensión del icono en Oriente: se puede afirmar o negar lo que es Dios, es decir, los iconos

8 Marco en forma de almendra que el arte románico y bizantino circunda algunas imágenes, especialmente la de Cristo (Diccionario de la Lengua Española, 2001). 
tienen conceptos catafáticos y apofáticos de lo que él es. De manera que en ellos es posible afirmar algunas realidades específicas de su esencia.

El sermón evidencia una postura catafática del evento: Dios se revela en la plenitud de una revelación progresiva de la divinidad de la persona del Hijo:

Esta figura estuvo oculta y escondida a los ojos de los mortales todo el tiempo que el Salvador vivió una vida encubierta [...] comenzó a descubrirse en su predicación y milagros, pero no acabó de salir a la luz hasta aquel día feliz en que se dejó ver lleno de gloria y majestad" (Anónimo, 1786, 1r).

Situación que concede la posibilidad de hacer epítetos positivos, debido a que el Verbo manifiesta y evidencia lo que es Dios. La evidencia por tanto es explícita: nos encontramos ante un sermón de teología catafática, donde se hace necesaria la Revelación para poder plasmar iconográficamente la "imagen de Dios", confirmando la Encarnación del Hijo.

\section{Revelación: Dios se da a conocer}

En esta sección se abordan algunos aspectos correspondientes a la visión de belleza y de gloria como cualidades específicas de Dios. El sermón desarrolla tres tipologías, donde se compara a Jesús con Judith, Elena de Troya y Moisés. Por último, se aborda el aspecto escatológico, que expone las tesis sobre el conocimiento de Dios por medio de los sentidos, y la comprensión del sermón sobre la fe y la esperanza.

\subsection{Belleza escatológica}

\subsubsection{Belleza testificada en la Transfiguración}

Dentro de los postulados sobre la belleza, Alvira distingue dos tipos: la belleza inteligible y la belleza sensible (1989, p. 165). La primera hace referencia a la bondad moral, es decir, va en contra de los vicios y pecados; la segunda posee un rango inferior debido a que es perceptible por medio de los sentidos. Cristo podría identificarse con la belleza inteligible, debido a su rectitud moral y su naturaleza divina, pero el sermón defiende la segunda postura: "Por eso el Salvador nos pone a la vista la imagen de la eterna [felicidad], para que, atraídos de su hermosura y grandeza, atropellemos cuantas dificultades nos detienen 
y peleemos como valerosos soldados hasta conseguir el premio" (Anónimo, 1786, 3r); es decir, Cristo manifiesta de manera sensible la belleza de la divinidad.

Sin embargo, debe distinguirse entre la lumen gloriae del evento teofánico de la Transfiguración y la visión beatífica: ver a la divinidad. La primera distingue un rasgo particular de la persona de Jesús, invitando a la credibilidad en su divinidad y a la animación en la fe. La segunda está directamente asociada a la visión de la esencia divina, de manera plena y eterna. En este sentido, aunque se asemejen, se distinguen debido al rango y objetivos que tienen: percibir la lumen gloriae en esta epifanía de Cristo, a diferencia de la contemplación plena y definitiva.

En Dios siempre la belleza se asocia con perfección, "llamamos a una cosa bella en sentido pleno cuando posee toda la perfección requerida por su naturaleza" (Alvira, Chavell y Melendo, 1989, p. 167), por ello, uno de los objetivos del sermón es defender la divinidad de Cristo, manifestada de manera evidente en la Transfiguración. La belleza de Cristo no es pasajera, sino perfecta debido a que su hermosura es fruto de su naturaleza divina en plenitud.

Dicha perfección invita al deseo de creer en ella y alcanzarla. Con esta intención, el sermón introduce el alcance escatológico de la Transfiguración: Cristo es glorificado plenamente, invitando al espectador a arder en deseo por llegar a esta plenitud. Al respecto, Agustín afirma: “Y primero le preguntaré si acaso las cosas son bellas porque agradan o al revés, si deleitan porque son bellas. Él, ciertamente, me responderá que agradan porque son bellas" (Agustín, 1956, p. 143), la belleza de Cristo es un deleite que se desea alcanzar.

Basilio asegura que en una imagen, ninguna de las partes es bella por sí misma, separada del resto pierde su valor estético, de allí que es bella solo en su totalidad (Zambruno, O. P., 2012, p. 31). La vida de Jesús está cargada de testimonio, pero al manifestar su naturaleza divina, evidencia la totalidad de su persona, es decir, desde su condición humana visualiza la gloria que en él habita. El sermón expresa que el Padre "para mirar por la honra de su Unigénito, transfiguró en el Tabor el rostro de Jesucristo lo hizo tan brillante y hermoso que representaba la gloria y majestad de Dios" (Anónimo, 1786, 1r). Así, en la persona de Jesús se manifiestan plenamente sus dos naturalezas, evidenciando la perfección tangible la belleza divina.

Dentro del pensamiento estético de Tomás de Aquino, se advierten tres características de la belleza que son atribuidas al Hijo, abordadas también por el sermón:

- Integridad o perfección: Tomás afirma que "lo inacabado, por ser inacabado, es feo" (I q. 39 a 8 co). Con referencia a Cristo afirma: "tiene 
semejanza con lo propio del Hijo, en cuanto que el Hijo tiene en sí mismo, de forma real y perfecta, la naturaleza del Padre" (i q. 39 a 8 co), naturaleza que se hace evidente en el sermón: "San Juan [...] refiere que vio la gloria de Jesucristo, pero una gloria tan sublime que no puede convenir sino al Unigénito del Padre" (Anónimo, 1786, 1v-2r).

- Proporción o armonía: para el Aquinate, “alguna imagen es bella si representa perfectamente al objeto" (I q. 39 a 8 co), por ello "también se adecua con lo propio del Hijo en cuanto que es Imagen expresa del Padre" (I q. 39 a 8 co), El sermón asegura que "Dios con el pincel de su entendimiento fecundo, pudo pintar en Jesucristo la figura de su misma substancia" (Anónimo, 1786, 1r) y "el Salvador nos pone a la vista la imagen eterna" (Anónimo, 1786, 1r).

- Claridad: Tomás dice: "lo que tiene nitidez de color es llamado bello" ( I q. 39 a 8 co), esto "se adecua al Hijo, en cuanto que es Palabra, que es lo mismo que decir Luz". En el sermón "la claridad del rostro de Jesucristo era un rasgo de su gloria" (Anónimo, 1786, 3r) que tiene un impacto en los receptores debido a que "la claridad de vuestro rostro la visión clara de vuestra gloria saciara mis ansias y llenara mis deseos" (Anónimo, 1786, 3r).

Es evidente que la estética de Tomás de Aquino influyó en el desarrollo del concepto "belleza" del sermón: en Cristo son aplicados a plenitud todos los rasgos fundamentales de lo bello, especialmente en la Transfiguración.

\subsubsection{Tipologías de belleza: Elena y Judith}

El sermón menciona dos mujeres que son ejemplo de belleza: Elena de Troya y Judith. La tipología que presenta con referencia a Jesús es la siguiente: 


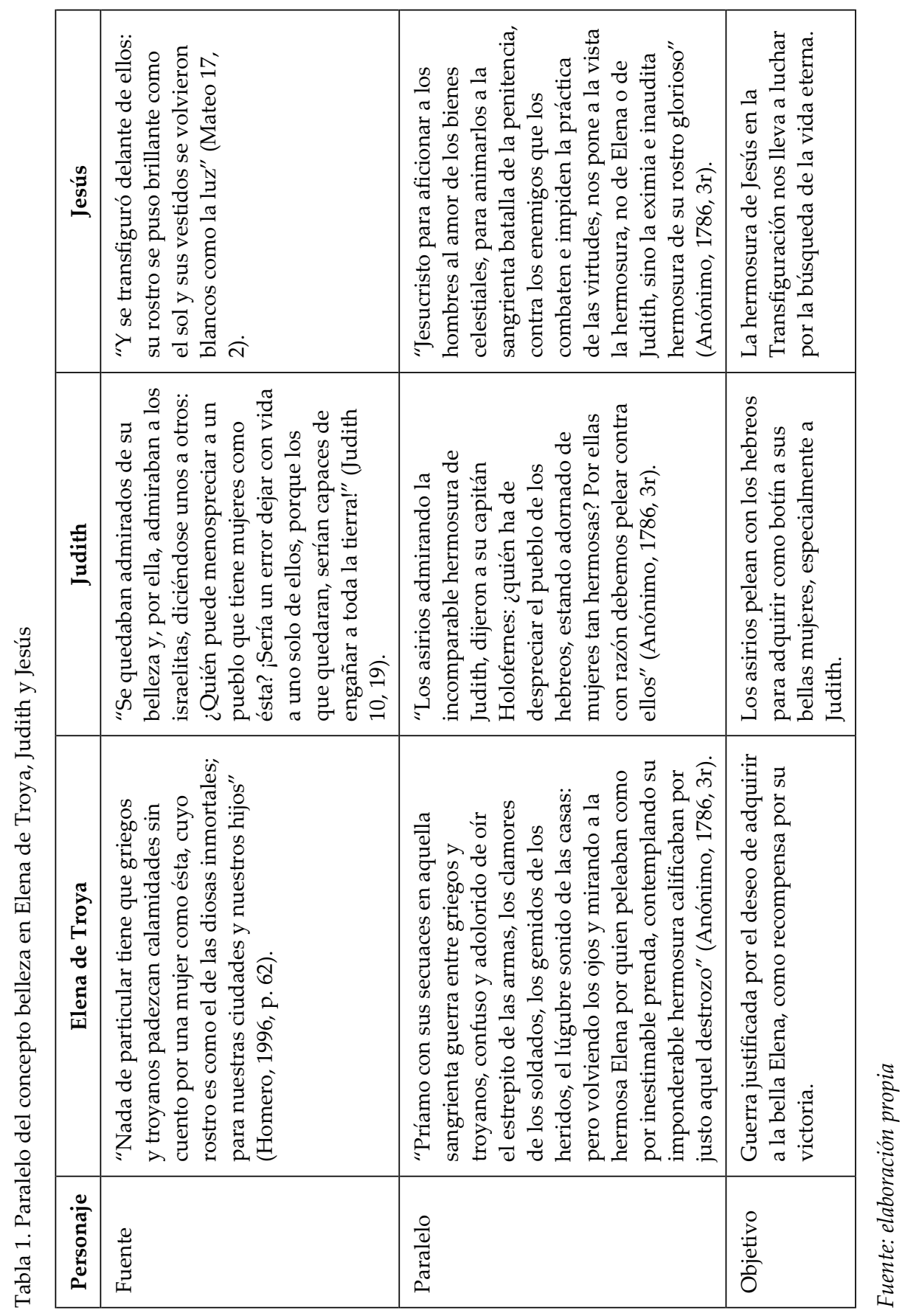


La tipología hecha sobre la hermosura de Cristo tiene un objetivo: inculcar en el expectante el ánimo en la lucha para conseguir a la vida eterna, con esto, la Transfiguración es evidencia de la gloria de Dios y testimonio prefigurado de cada creyente en la eternidad. Los cristianos deben procurar cumplir a cabalidad los designios morales y aceptar por medio la fe a la persona de Jesucristo para poder adquirir la Felicidad plena. Así como se suscitó una guerra entre los pueblos por adquirir la belleza de una mujer, también se requiere un camino de sacrificios que conduzca a la contemplación de la belleza suprema reflejada en Cristo, guerra que se podría traducir como camino de penitencia o sacrificio para llegar a gloria eterna.

\subsubsection{Hermosura del rostro}

El evangelio de Mateo tiene dentro de sus objetivos mostrar a Jesús como un nuevo Moisés:

El primer evangelio insinúa, [...] que Jesús es un nuevo Moisés, liberado de una muerte amenazadora, que será Libertador y Conductor de su pueblo, recibirá de Dios una Ley nueva que no destruirá la antigua, sino que ésta será llevada a su plenitud" (Carrillo Alday, 2010, p. 72).

Por ello en la Transfiguración se rescatan actitudes y cualidades de Jesús que hacen referencia directa a este personaje. "Moisés" es mencionado nueve veces en el sermón, mostrando la relevancia que tiene para la comprensión de la perícopa evangélica, evidenciando la superioridad del Mesías en los siguientes aspectos (Anónimo, 1786, 2v): 
Tabla 2. Paralelo entre Moisés y Jesús

\begin{tabular}{|l|l|l|}
\hline \multicolumn{1}{|c|}{ Descripción } & \multicolumn{1}{|c|}{ Moisés } & \multicolumn{1}{c|}{ Jesús } \\
\hline $\begin{array}{l}\text { Brillo del } \\
\text { rostro }\end{array}$ & $\begin{array}{l}\text { Despedía tan claros resplandores } \\
\text { que los israelitas no podía fijar la } \\
\text { vista en su rostro. }\end{array}$ & $\begin{array}{l}\text { Pero no brillaba tanto como el } \\
\text { rostro de Jesucristo. }\end{array}$ \\
\hline $\begin{array}{l}\text { Brillo de todo } \\
\text { el cuerpo }\end{array}$ & Solo el rostro resplandecía. & $\begin{array}{l}\text { Por todas partes despedía luces } \\
\text { más claras que el sol. }\end{array}$ \\
\hline $\begin{array}{l}\text { El velo y las } \\
\text { vestiduras }\end{array}$ & $\begin{array}{l}\text { Cubría la gloria de su rostro con } \\
\text { un velo. }\end{array}$ & $\begin{array}{l}\text { Los resplandores no podían } \\
\text { ser encubiertos porque } \\
\text { traspasaban y salían sobre los } \\
\text { mismos vestidos. }\end{array}$ \\
\hline $\begin{array}{l}\text { Efecto de la } \\
\text { claridad }\end{array}$ & $\begin{array}{l}\text { Los rayos de luces que despedía } \\
\text { el rostro embarazaban la vista de } \\
\text { los israelitas. }\end{array}$ & $\begin{array}{l}\text { Las luces del rostro llenaban de } \\
\text { suavidad y dulzura los ojos de } \\
\text { los apóstoles. }\end{array}$ \\
\hline $\begin{array}{l}\text { Procedencia de } \\
\text { la claridad }\end{array}$ & $\begin{array}{l}\text { La claridad del rostro, puramente } \\
\text { figuraba que él penetraba todo } \\
\text { el espíritu de la Ley, que había } \\
\text { recibido en el monte y que } \\
\text { anunciaba al Pueblo de Dios. }\end{array}$ & $\begin{array}{l}\text { La claridad del rostro de } \\
\text { Jesucristo era un rasgo de su } \\
\text { gloria. }\end{array}$ \\
\hline
\end{tabular}

Fuente: elaboración propia

Para el evangelista, Jesús supera a Moisés comprobando la procedencia divina y el cumplimiento de las promesas mesiánicas en él. El mandato impartido por la voz en la Transfiguración, “Este es mi Hijo amado, en quien me complazco; escuchadle" (Mateo 17, 5), manifiesta el precepto de escuchar a Jesús como un nuevo Moisés. Al final solo queda él "porque solo él basta como Doctor de la Ley perfecta y definitiva" (Ramos, 2001).

\subsection{Premios esperados: gloria que nos espera}

\subsubsection{La Transfiguración es el mejor testimonio de la gloria, sin epítetos ni hombres}

La Transfiguración ha pasado por diferentes procesos de interpretación en lo que se refiere al concepto "gloria". Se destaca el estado de gloria de Cristo como prefiguración de la que le espera a la humanidad redimida. El sermón apoya este 
argumento al defender que no se necesitan más explicaciones sobre la gloria que espera a los creyentes: "Solo con manifestarse Jesucristo a los tres Apóstoles en aquel estado de gloria y de majestad nos dio una idea de la eterna felicidad" (Anónimo, 1786, 3r). Con esto, basándose en términos tomistas, donde el "fin del hombre es el bien increado, o sea Dios [...] el último fin se llama bienaventuranza" (Martínez Puche O. P., 2003), se muestra una plenitud de la gloria y de la apertura de la salvación a toda la humanidad.

La gloria "hace referencia principalmente a la perfección intrínseca que posee Dios, pero que no guarda para sí, y que libremente manifiesta y comunica a las criaturas" (Izquierdo, 2006). Así, la soteriología evidencia el deseo de Dios por la salvación del hombre como constructo pleno de su creación. Este aspecto no se reserva a Dios, sino que se extiende a todos los hombres: "el Hijo hecho hombre manifiesta y comunica la gloria divina a los hombres, transformándolos pneumatológicamente en hijos gloriosos y asociándolos a su acto de perfecta glorificación del Padre" (Izquierdo, 2006).

La gloria se vincula con la acción realizada en su cuerpo, denominado "cuerpo glorioso", es decir, "la sustracción del cuerpo ha sido objeto de una profunda transformación, en virtud de la cual pasa a ser 'el cuerpo de su gloria'"' (Izquierdo, 2006). El sermón afirma:

¡Tanto es lo que arrebata sola la imagen de la gloria! [...] Si un solo destello de la gloria y de la majestad del Hijo de Dios arrebata la admiración, colma los deseos, satisface las ansias, inunda en tan puro, en tan exquisito gozo a los que son testigos de Él. (Anónimo, 1786, 4r)

Es posible que la interpretación lleve a categorizar la Transfiguración como un evento superior frente a otros sucesos que manifiestan la glorificación de Cristo, como la Resurrección, teoría que se rompe con la explicitación de los objetivos del sermón: aumentar la fe en Cristo como verdadero Dios y manifestar el sentido escatológico de la resurrección del hombre(Anónimo, 1786, 4r), concluyendo que su finalidad no es demostrar la supremacía de la Transfiguración sobre otros hechos, sino comunicar la naturaleza divina de Jesús, permitiendo animar la fe en Dios y aumentar la esperanza en la glorificación del hombre.

Los Padres han asociado la resurrección de Cristo con la humanidad. Clemente de Roma, en la Carta a los Corintios, invita a sus lectores a reflexionar "cómo el Señor nos muestra continuamente nuestra futura resurrección, de la cual hizo primicia al Señor Jesucristo resucitándolo de entre los muertos" 
(1994, p. 105). Novaciano afirma que "se establece la ley de la resurrección cuando Cristo, como modelo de todos los demás, resucita en la substancia de su cuerpo" (1996, p. 125), es decir, se puede hablar de la resurrección del hombre, gracias a la resurrección de Cristo.

La resurrección abre las puertas de la gloria al cristiano, que ya ha evidenciado una prefiguración de su felicidad eterna en la Transfiguración. Así, estos dos términos poseen un vínculo íntimo en la vida del creyente, donde se manifiesta el objetivo mismo de la creación: la gloria eterna.

\subsubsection{Gloria incomparable}

El sermón, al referirse del apóstol Juan afirma que "fue uno de los testigos oculares que se halló presente en el Tabor, refiere que vio la gloria de Jesucristo, pero una gloria tan sublime que no puede convenir sino al Unigénito del Padre" (Anónimo, 1786, 2r). La gloria emanada por Cristo no es la de cualquier mortal, sino la del mismo Dios.

Los Padres no desvinculan la gloria de la relación intratrinitaria, de manera que se invoca en diferentes doxologías la gloria divina:

- En la Didaché: “Porque tuyo es el poder y la gloria" (1992, p. 99) “A ti la gloria por los siglos". "Porque tuya es la gloria y el poder por los siglos por medio de Jesucristo" (1992, p. 99).

- $\quad$ En Clemente de Roma: “El gran Creador y Señor del universo mandó que todas estas cosas se mantuvieran en paz y concordia, derramando el bien [...] sobre nosotros que nos hemos refugiado en sus misericordias por medio de nuestro Señor Jesucristo. A él la gloria y la grandeza por los siglos de los siglos. Amén” (1994, pág. 101); “¿O Ananías, Azarías y Misael fueron encerrados en el horno de fuego por los que observaron la magnífica y gloriosa religión del altísimo?" (1994, p. 125).

- $\quad$ En el Martirio de Policarpo: “Una vez que os hayáis informado de estos acontecimientos, enviad la carta a los hermanos que están lejos, para que también ellos glorifiquen al Señor que escoge a los elegidos de entre sus propios siervos" (Carta de la iglesia de Esmirna a la iglesia de Filomelio, 2000, pp. 336-337). “Al que puede introducirnos a todos por su gracia y don, en su Reino eterno, por medio de su Hijo unigénito Jesucristo, a Él la gloria, el honor, el poder y la grandeza por los siglos" (Carta de la iglesia de Esmirna a la iglesia de Filomelio, 2000, 
pp. 336-337). “A Él (Jesucristo) la gloria junto con el Padre y el Espíritu Santo por los siglos de los siglos. Amén" (Carta de la iglesia de Esmirna a la iglesia de Filomelio, 2000, pp. 336-337).

La oración de la Iglesia es una constante alabanza de la gloria divina. El vínculo trinitario incluye este atributo de manera equitativa a las tres personas, reconociendo en ella, la manifestación de la naturaleza divina.

Rahner distingue dos tipos de gloria: objetiva, la cual es desempeñada por "cada una de sus creaturas en cuanto que es y refleja [...] algo de la divina perfección" (1964, p. 460); y formal "porque la creatura libre y dotada de espíritu reconoce en libertad amorosa la superioridad sin límites de Dios" (1964, p. 460). El Cristo glorificado en la Transfiguración anima la esperanza de los espectadores, quienes anhelan una participación futura de su gloria (objetiva) y reconocen la naturaleza divina de Jesús (formal).

El desarrollo del concepto "gloria" desde el sermón y los diferentes aportes teológicos, evidencian esta cualidad como un aspecto divino, participado a la humanidad por generosidad de Dios. De esta manera, los hombres poseen la gloria que Dios ha confiado por medio de su Hijo, lo que permite afirmar que la humanidad es glorificada por la gloria misma de Dios.

\subsection{Fe esperanzadora}

La fe es concebida desde el Catecismo como "la respuesta libre del hombre a la iniciativa de Dios que se revela" (Catecismo de la Iglesia Católica, 1993, p. 50). Esta afirmación, por sencilla que parezca, contiene dos argumentos indispensables en la teología cristiana: primero, es Dios quien se da a conocer, comunicando al hombre el mensaje de la salvación por medio de su Hijo; segundo, el acto de fe es la manera como el hombre responde a la revelación. Partiendo de este presupuesto, el sermón afirma que "Jesucristo se dejó ver lleno de gloria y de majestad para apoyar la fe" (Anónimo, 1786, 1r), es decir, en la Transfiguración se hace evidente la iniciativa autocomunicadora de Dios, mostrándose gloriosamente frente a los apóstoles, confirmando su fe, y con ellos, la de toda la Iglesia.

\subsubsection{La fe como creencia en el contenido doctrinal}

Algunos Padres se interesaron por el contenido de la fe (De Simone, 1998, p. 860), lo cual hizo que todo el desarrollo dogmático de los primeros siglos, poseyera el 
asentimiento de la Iglesia para a hacer parte de la doctrina de fe. Es por ello que ya la Didaché la rescata como una separación del cristiano, frente a los judíos y paganos (Didaché, 1992, p. 109), generando una identidad del cristianismo frente a otras prácticas y creencias.

Clemente de Roma comprende la fe desde "las profundidades del conocimiento de Dios" (1994, p. 123), es decir, el estudio del misterio de Dios revelado en su Hijo, comprendiéndose como una filiación dogmática al misterio de Cristo. Ignacio de Antioquía apoya esta idea al afirmar que es necesario alcanzar "el conocimiento de Dios que es Jesucristo" (1999, p. 121) y Justino sintetiza el asunto asegurando que: credant in hunc Iesum crucifixum, agnoscentes eum ese Christum Dei (1857, p. 574).

Dentro del pensamiento escolástico, Tomás destaca que "no formamos enunciados sino para alcanzar el conocimiento de las realidades; como ocurre con la ciencia, ocurre también en la fe" (santo Tomás, II-II, q.1. a. 2 ad 2), mostrando de esta manera a la fe como la ciencia de Dios mismo. El predicador de 1786 parte de este argumento al manifestar uno de los objetivos de la Transfiguración: "quiso Jesucristo manifestarse a sus discípulos para fortificar su tierna fe" (Anónimo, 1786, 1v). La perícopa evangélica centraliza la respuesta del creyente en la persona de Jesucristo.

Ahora bien, dentro del contenido doctrinal, se centra en un argumento: reconocer a Jesús como verdadero Dios. Este ha sido un elemento estudiado y desarrollado por los primeros concilios de la Iglesia. La particularidad en la Transfiguración está en que es expuesto como un ser divino de forma visible, manifestando dicha naturaleza antes de su Pascua.

La fe se vincula explícitamente con el reconocimiento de Cristo como Dios, siendo esta teofanía un evento palpable y fiel de su naturaleza divina. La fe se convierte en la filiación o el asentimiento del creyente frente a una verdad de fe (naturaleza divina de Cristo), aumentando con ello la credibilidad y la razonabilidad de lo que se cree.

La Transfiguración es una evidencia, para a los sentidos, la divinidad: el Dios incorruptible manifiesta su gloria, dejándola conocer por los sentidos corruptibles del hombre. Es necesario recordar que "solo resta conocer lo Incognoscible con la gracia divina y mediante el Logos que procede de él" (Clemente de Alejandría, 2003, p. 463), es decir, el Padre revela su divinidad, por medio del Hijo.

En el desarrollo de la categoría: conocimiento de Dios, el sermón sostiene una tesis, tal vez impactante para la época: no obstante, el arrebato místico o el destino del ser humano respecto de la contemplación de Dios, los apóstoles en la 
Transfiguración conocieron, por medio de sus sentidos, una manifestación de la gloria de Dios (lumen gloriae), y no la esencia de Dios. Así, la Transfiguración es un grado de participación en la manifestación divina, a la manera de un enunciado, no de un contenido, superando, empero, su sola intuición, pues Cristo quiso manifestárseles.

\begin{abstract}
Solo con manifestarse Jesucristo a los tres Apóstoles en aquel estado de gloria y de majestad nos dio una idea de la eterna felicidad, mucho más clara que la que formaríamos con los epítetos y nombres, con que las letras sagradas explican su dignidad y excelencia. Aunque David la llama monte encumbrado, fuente clara y permanente, torrente de delicias, apreciable tabernáculo, paz suma e inalterable; aunque San Juan la titula, fin de los trabajos y descanso de las fatigas, bodas del cordero inmaculado y Jerusalén triunfante, aunque estos nombres comprueban su dignidad, pero como ella excede a todo sentido y a toda penetración, no podía movernos a su aprecio con tanta fuerza y eficacia, como entrando a nuestros corazones por las ventanas de los sentidos. Aunque San Pablo fue arrebatado al tercer cielo, donde vio la divina esencia, con todo, hablando de la bienaventuranza nos dice: que ni los ojos han visto, ni los oídos han oído, ni el corazón ha penetrado los bienes que Dios tiene preparados para quienes verdaderamente le aman. (Anónimo, 1786, 3v)
\end{abstract}

El sermón plantea cómo Pablo fue arrebatado al tercer cielo y vio la divina esencia, sin embargo, refiriéndose a la bienaventuranza, asegura que: "lo que ni el ojo vio, ni el oído oyó, ni al corazón del hombre llegó, lo que Dios preparó para los que le aman" (1 Cor 2, 9). ¿Quiere el predicador decir que el arrebato de Pablo constituye una forma de participación semejante a la de los apóstoles en la Transfiguración? De todas maneras, no se trataría de un conocimiento de Dios basado en la sola intuición, sino en una capacidad de los sentidos en relación con la manifestación divina y su conocimiento. Se abre aquí paso al acto de fe.

Izquierdo plantea una cuestión “¿cómo sabemos que algo es real, es decir, que existe realmente en sí mismo y no solamente en el conocimiento de alguien?" (2012, p. 16), respondiendo que "es preciso ante todo tener noticia de ese algo, y esa noticia la tenemos por nosotros mismos, que conocemos por los sentidos o deducimos a partir de otras cosas lo que está detrás de ellas" (2012, p. 16). Los sentidos se convierten en una manera de conocimiento, pero comprendido en un conocimiento del mundo. Ahora, ¿cómo vincular esto a la esencia divina?, ¿es posible conocerla? 
El mismo Izquierdo vincula la persona del Padre al término Deus absconditus, además con cualidades como "invisibilidad y silencio" (2012, p. 68). Con la revelación del Hijo, se convierte en Deus revelatus, utilizando dos sentidos opuestos a las cualidades del Padre: el oído, en contraposición al silencio; y la vista, en contra la invisibilidad (Izquierdo, 2012, p. 69). El Hijo se hace la voz de Dios y la exterioridad visible de su esencia.

En esta pieza homilética del Virreinato granadino, se encuentra una interpretación bíblica que bien podría polemizar con las problemáticas planteadas posteriormente por la epistemología positivista, la cual “afirmará que los sentidos son la única fuente de conocimiento, y no nos proporcionan ningún dato sobre la existencia de Dios" (González, 2015, p. 41). El predicador, al asegurar que "allí fue el teatro donde se hizo visible a nuestros torpes sentidos" (Anónimo, 1786, 3v), confrontaría un conocimiento de Dios sensitivamente a través de la Transfiguración, como si los apóstoles hubieran percibido la esencia divina, y no la gloria que el Padre manifestó en su Hijo, confirmando la procedencia divina del Verbo. La Transfiguración podría entonces entenderse como una pedagogía superior de Dios hacia el hombre.

\subsubsection{Creer y anhelar}

La fe y la esperanza han tenido un íntimo vínculo en su desarrollo teológico. Algunos Padres, como Clemente de Alejandría, las comprendieron relacionalmente:

La Iglesia, como el hombre, está formada por muchos miembros, saca su fuerza y su crecimiento, su trabazón y su consistencia de dos elementos: de la fe que es cuerpo y de la esperanza que es el alma, al igual que el Señor, que tenía carne y sangre. La esperanza es realmente la sangre de la fe. Si la esperanza se desvanece, como sangre que se derrama, la fuerza vital de la fe se debilita. (2009, p. 157).

Ratzinger habla de esta relación, centralizándola en la persona de Cristo: "Dios sólo se hace concreto en Cristo, nuestra esperanza sólo se hace concreta en la fe en Cristo" (2007, p. 302). Con ello, la fe posee una conexión especial con la esperanza, donde se cree en la redención de los hombres y en la gloria futura que les espera.

El sermón desarrolla la relación íntima que existe entre fe y esperanza: "Pero la fe y la esperanza son dos muros que atajan estas entumecidas olas con que el mar del mundo intenta combatir el cristianismo" (Anónimo, 1786, 4v). Lo anterior 
podría llevar a la confusión de comprender la fe y la esperanza como conceptos similares, pero se hace una sutileza particular de cada una de ellas: "Jesucristo que en su transfiguración confirmó nuestra fe y fortaleció nuestra esperanza, convidándonos a seguir sus pisadas con el suave atractivo de su gloria, alumbre nuestro entendimiento para conocerle, excite nuestra voluntad para amarle y gustar las delicias interminables de la Patria celestial" (Anónimo, 1786, 4v). Se hace una distinción entre estas virtudes teologales. La fe está vinculada con el acto de creer en Cristo, específicamente en su naturaleza divina, evidenciada en la gloria de Jesús, la cual es prefiguración del futuro de la humanidad redimida. De esta manera, por acto de fe, se cree en la futura resurrección. La esperanza es concebida como el anhelo o deseo que anima al creyente a poder llegar a dicha gloria, es decir, por fe creemos en la vida eterna, con la esperanza anhelamos llegar a ella.

\section{Conclusiones}

Del estudio teológico del sermón inédito De Transfiguración: Transfiguratus est ante eos (Mt 17, 2) del Fondo Sermones del Archivo Histórico de la Provincia dominicana de San Luis Bertrán de Colombia, se pueden llegar a las siguientes conclusiones:

- La Transfiguración de Cristo es una acción abierta a la humanidad, entendida de manera física, terrenal y escatológica. Física y terrenal porque se comprende en el hombre como un cambio moral o corporal. Escatológica porque en Cristo transfigurado de manera gloriosa, se evidencia el futuro prometido a la humanidad: la gloria de Cristo en la Transfiguración, es la gloria que el hombre anhela obtener.

- El sermón al mencionar a los pintores clásicos de la cultura greco-romana, evidencia la diferencia entre los iconos del Dios Revelado y los ídolos. Cristo: el Verbo encarnado puede ser plasmado materialmente. Así, el autor del sermón hace una defensa de la teología catafática, donde Dios se hace perceptible a los sentidos humanos, permitiendo a los apóstoles conocer una manifestación de su gloria, desde la perspectiva de la Encarnación, la cual se puede plasmar en los iconos.

- Se enfatiza la Transfiguración como hecho que anima la virtud de la esperanza, debido a que en la "hermosura" de la manifestación gloriosa, se evidencia la meta del cristiano al finalizar su vida, haciéndose 
necesaria la lucha por alcanzar el anhelado "premio". La belleza de Dios, viene a representar la invitación que ansía el creyente, es decir, a animar la Esperanza.

- La Transfiguración acrecienta la Fe en Cristo. Este objetivo del sermón va de la mano con la virtud de la Esperanza, siendo la Fe la acción de "creer" y la Esperanza el "anhelo de lo que se cree".

- Finalmente, la predicación de los frailes dominicos neogranadinos del siglo xviII, contenida en las unidades archivísticas no se deben considerar piezas de museo, sino verdaderas fuentes de interpretación teológica y para la historia del Iglesia y de la teología.

- El estudio historiográfico y teológico del patrimonio documental contenido en el Archivo Histórico de la Provincia de San Luis Bertrán de Colombia, es pertinente para el desarrollo interdisciplinar de la identidad científica de la Facultad de Teología de la Universidad Santo Tomás-Bogotá.

\section{Referencias}

\section{Fuente documental inédita}

AнPSBC. Fondo Sermones. (1786). Sermón de Transfiguración: Transfiguratus est ante eos (Mt 17, 2). Caja 1-Carpeta 1: II, anónimo, 1r-4v, predicado en Santa Fe, 1786, 1r.

\section{Fuentes y ediciones críticas}

Anónimo. (1781). Año Christiano o Exercicios Devotos. Imprenta de Andrés de Sotos.

Fr. Benito Gil Bezerra. (1739). Paraíso de Oraciones Sagradas. Imprenta de Joseph Giralt.

\section{Bibliografía}

Agustín. (1845). Sermón LXXVIII. En J. Migne (ed.), Patrologiae, Cursus Completus, Opera Omnia. Parisis.

Agustín. (1950). Obras de San Agustín. Biblioteca de Autores Cristianos.

Agustín. (1956). Obras Completas. Tomo IV. Biblioteca de Autores Cristianos.

\section{Universidad Santo Tomás, Facultad de Teología}


Álvarez Gómez, J. (1998). Arqueología cristiana. Biblioteca de Autores Cristianos.

Alvira, T., Chavell, L. y Melendo, T. (1989). Metafísica. Ediciones Universidad de Navarra (Eunsa).

Ambrosio. (1845). Expositio Evangelii Secundum Lucam. En J. Migne (ed.), Patrologiae, Cursus Completus, Opera Omnia. Parisis.

Ambrosio. (1966). Tratado sobre el Evangelio de San Lucas. Biblioteca de Autores Cristianos.

Anónimo. (1992). Didaché. Ciudad Nueva.

Asterio de Amasea. (1996). Panegírico de Santa Eufemia. En J. Plazaola (ed.), Historia y sentido del arte cristiano (pp. 79-80). Biblioteca de Autores Cristianos.

Basilio de Cesarea. (2012). El Espíritu Santo. Ciudad Nueva.

Blanco Freijeiro, A. (2011). Arte Griego. Consejo Superior de Investigaciones Científicas.

Bonhoeffer, D. (2000). Ética. Editorial Trotta.

Cantalemessa, R. (2003). El misterio de la Transfiguración. Monte Carmelo.

Carrillo Alday, S. (2010). El evangelio según san Mateo. Editorial Verbo Divino.

Carta de la iglesia de Esmirna a la iglesia de Filomelio. (2000). En Padres Apostólicos (pp. 323-338). Ciudad Nueva.

La Santa Sede. (1993). Catecismo de la Iglesia católica. (1993). Conferencia Episcopal de Colombia.

Cirilo de Jerusalén. (1945). Las catequesis. Ediciones Aspas.

Clemente de Alejandría. (2003). Stromata IV-V. Ciudad Nueva.

Clemente de Alejandría. (2008). El proteptico. Ciudad Nueva.

Clemente de Alejandría. (2009). El pedagogo. Ciudad Nueva.

Clemente de Roma. (1994). Carta a los Corintios. Ciudad Nueva.

Codina, V. (1997). Los caminos del Oriente cristiano. Sal Terrae Editores.

De La Maza, J. (2013). La Inauguración de la academia. Universidad Alberto Hurtado.

De Miguel, R. (1889). Nuevo diccionario. Latino-español etimológico. Editorial Agustín Jubera.

De San Miguel, F. (1846). La Biblia Vulgata latina. De L'ecointe.

De Simone, R. (1998). Fe. En A. Di Bernardino (coord.), Diccionario patrístico y de la antigüedad cristiana (pp. 860-865). Ediciones Sígueme.

Dezinger, H. Hünermann, P. (1999). El Magisterio de la Iglesia. Enchiridion Symbolorum Definitionum et Declarationum de Rebus Fidei et Morum. Herder Editorial.

Larousse. (2011). Diccionario ilustrado latino-español VOX. (2011). Larousse. 
Drobner, H. (1999). Manual de patrología. Herder Editorial.

Espasa-Calpe. (1920). Enciclopedia Universal Ilustrada. Espasa.

Eusebio de Cesarea. (1999). Carta a Constanza. En S. Christoph (ed.), El icono de Cristo: Una introducción teológica. Ediciones Encuentro.

Evdokimov, P. (1991). El arte del icono. Publicaciones Claretianas.

Felmy, K. C. (2002). Teología ortodoxa actual. Ediciones Sígueme.

Franquesa, A. (2002). El Segundo Conilio de Nicea y el Icono. En Los Iconos (pp. 33-54). Centre de Pastoral Litúrgica.

Germán de Constantinopla. (2001). Homilías mariológicas. Ciudad Nueva.

González, Á. (2015). Teología natural. Ediciones Universidad de Navarra (Eunsa).

González de Cardedal, O. (2001). Cristología. Biblioteca de Autores Cristianos.

Gregorio Magno. (1996). Carta a Sereno. En J. Plazaola (ed.), Historia y Sentido del Arte Cristiano (pp. 175-176). Biblioteca de Autores Cristianos.

Homero. (1996). La Ilíada. EDAF.

Ignacio de Antioquía. (1999). Carta a los efesios. Ciudad Nueva.

Izquierdo, C. (2006). Diccionario de teología. Ediciones Universidad de Navarra (Eunsa).

Izquierdo, C. (2012). La luminosa oscuridad de la fe: los misterios cristianos. Ediciones Universidad de Navarra (Eunsa).

Juan Damasceno. (2004). De imaginibus oratio. En J. Camaño (ed.), La dinámica simbólica de las imágenes en la Teología de las Imágenes de San Juan Damasceno. Pontificia Universidad Católica de Argentina.

Justino. (1857). Dialogus Cum Tryphone Judae. En A. Migne (ed.), Patrologiae, Cursus Completus, Opera Omnia. Parisis.

Lactancio. (1996). Divinarum Istitutionum. En J. Plazaola (ed.), Historia y Sentido del Arte Cristiano (p. 20). Biblioteca de Autores Cristianos.

Lorda, J. y Álvarez, A. (2016). Antropología teológica. Ediciones Universidad de Navarra (Eunsa).

Lozano, J. M. (2014). Historia del Arte. Publicaciones Cultural.

Marfiori y Cuello, E. (2010). La teología de la Transfigración en los Padres latinos. Universidad de Navarra.

Martínez Lozano, E. (2013). El gozo de ser persona. Narcea.

Martínez Puche O. P., J. (2003). Diccionario teológico de Santo Tomás. Madrid: Edibesa.

Nestle - Aland. (1991). Novum Testamentum Graece. Deutsche Bibelgesellschaft.

Novaciano. (1996). La Trinidad. Ciudad Nueva. 
Orígenes. (1967). Contra Celso. Biblioteca de Autores Cristianos.

Peultier, Etienne, y Gantois. (1939). Concordantiarum Universae Scripturae Sacrae. Sumptibus P. Lethielleux Editoris.

Plazaola, J. (1996). Historia y sentido del arte cristiano. Biblioteca de Autores Cristianos.

Pozo, C. (1993). La venida del Señor en la gloria. Editorial Cultural y Espiritual Popular (Edicep).

Rahner, K. (1964). Escritos de teología V. Taurus Ediciones.

Ramos, F. (2001). Diccionario de Jesús de Nazaret. Monte Carmelo.

Rashi. (14 de marzo de 2019). Sefaria. Sefaria. https://www.sefaria.org/Rashi_on_II_ Samuel.3.3.1-2?lang=bi

Ratzinger, J. (2007). Escatología: la muerte y la vida eterna. Barcelona: Herder Editorial.

Teodoro Estudita. (1996). Antirrheticus. En J. Plazaola (ed.), Historia y sentido del arte cristiano (p. 198). Biblioteca de Autores Cristianos.

Tomás de Aquino. (1988). Suma de teología. Biblioteca de Autores Cristianos.

Vásquez Alarcón, F. y Vergara Abril, H. (2019). Vocabulario Griego-Español. Kimpres.

Vilanova, E. (1987). Historia de la teología cristiana. Herder Editorial.

Zabalza Iriarte O. P., J. (2004). La filosofía colonial ¿Nuestra tardía Edad Media? En G. Marquínez, R. Salazar, E. Rodríguez, J. Zabalza, D. Herrera, \& L. Tovar, La filosofía en Colombia (pp. 107-134). Editorial El Búho.

Zambruno, O. P., P. (2012). Via Pulchritudinis. Ensayo de Estética Tomista. Instituto Lumen Sapientiae. 